\title{
Zhuangzhi Sun* \\ Progress and Prospects: Sino-Russian Strategic Coordination in Multilateral Mechanisms
}

https://doi.org/10.1515/cjss-2021-2006

Published online August 26, 2021

Abstract: As China and Russia face a complex international and neighborhood environment with many uncertainties and real security threats, it is of special significance to strengthen cooperation within the multilateral framework at the regional and higher level, including leading the establishment of new regional cooperation mechanisms such as the Shanghai Cooperation Organization (SCO). China and Russia are interacting in global and regional frameworks such as the United Nations (U.N.), BRICS, G20, APEC, and the Conference on Interaction and Confidence-Building Measures in Asia, and jointly promoting cooperation between the Belt and Road Initiative and the Eurasian Economic Union. All of these add more connotations and richer levels of cooperation in the Sino-Russian comprehensive strategic partnership of coordination in the new era. The two countries share the same or similar views on many international and regional issues and have extensive common interests in security, economic and political fields, which is an important prerequisite and basis for multilateral cooperation. There are inevitable differences between the two major powers in goals on regional issues, yet those differences haven't become substantial obstacles to multilateral cooperation. Looking forward, with the complex changes in the international situation, especially in the post-pandemic era when there will be significant adjustments in the economic, political and security landscape, close cooperation between China and Russia within multilateral mechanisms can play an increasingly important role in improving the global and regional governance system, maintaining multilateralism and steering the international landscape in a more just and rational direction.

Keywords: multilateral mechanism, China, Russia, strategic cooperation, Shanghai Cooperation Organization

\footnotetext{
*Corresponding author: Zhuangzhi Sun, Research Fellow and Director, Institute of Russian, Eastern European, Central Asia Studies, Chinese Academy of Social Sciences, Beijing, China, E-mail: sunzz@cass.org.cn
} 
China and Russia are both the world's powerhouses, and their political, economic and security cooperation is vital for regional and even global stability. Since China and Russia are facing a very complex surrounding environment with uncertainties and threats, it is of strategic value to strengthen their cooperation at the regional level, including leading the establishment of regional cooperation mechanisms. After the Shanghai Cooperation Organization (SCO) was established in June 2001, China and Russia started to expand multi-lateral cooperation. In July of the same year, the two sides signed the landmark Treaty of Good-Neighborliness and Friendly Cooperation between the People's Republic of China and the Russian Federation, which not only provides norms for the development of bilateral relations, but also solidifies the principles that the two countries follow in international and regional affairs. In the future, the extent to which the SCO can play a role depends to a large extent on the closeness of Sino-Russian relations. It can be said that the establishment of bilateral strategic partnership between China and Russia is a prerequisite for multilateral cooperation within the SCO framework.

\section{Strengthened Multilateral Cooperation Driven by Common Interests}

The close cooperation between China and Russia in international organizations, e.g. the United Nations, and multilateral frameworks help improve the global and regional governance system and are in line with the long-term strategic interests of both countries. The establishment of the Shanghai Cooperation Organization, mainly promoted by China and Russia, is a fruit of the sound development of SinoRussian strategic partnership of coordination, a logical extension of bilateral relations at the regional level, and a contribution to the joint maintenance of regional stability and development.

\subsection{The Bounded Security and Economic Interests Require Countries in Central Asia to Address Issues and Challenges Together}

Central Asia is considered by Russia as its important strategic "backyard" for the following reasons. First, the stability of Central Asia determines the security of the southern part of Russia. Second, Central Asia is an indispensable sales market and raw material supplier for Russia. Third, Russia is in need of the right to explore mineral resources in this area, and thus taking a favorable position in the regional 
competition for resources and maintaining its status as a great power. Fourth, Russia wants to use military and industrial facilities in Central Asia. Fifth, it is Russia's gateway to West and South Asia. Sixth, the establishment of a regional collective security system, as well as safeguarding the rights of the Russianspeaking population, helps prevent the refugees from flooding into Russia. Hence, Russia has to ensure a strong position in Central Asia for the sake of its own interests and cannot tolerate Central Asian countries stepping far away from itself or even going to the opposite side.

Central Asia deserves the attention from China as well. In order to ensure stability and sustainable development, China is in great need of a stable surrounding environment, in which Central Asia, as China's close neighbor, constitutes an important part. The economic growth and resource exploration of Central Asian countries provide new opportunities for China's economy, especially in northwestern China. Besides, non-traditional security issues in Central Asia also have a direct impact on China. With a common border of about 3,300 km, China also expects Central Asian countries to pursue a friendly policy toward China in order to safeguard its national interests. China is opposed to external forces creating instability in Central Asia and interfering in the internal affairs of Central Asian countries which may result in the detriment of the interests and security of countries in this region.

Therefore, as Central Asia's immediate neighbors, both China and Russia need to ensure security in this region, stabilize their own borders and consolidate each other's strategic rears (Yang, 2017). They can also promote regional cooperation in economy, resource development and transportation, and help Central Asian countries develop their economies while moving towards international markets.

\subsection{Enhance Regional Influence and Maintain and Improve International Status}

China is the world's largest developing country, and Russia, whose economic power once plummeted after the collapse of the Soviet Union, is struggling to regain its weight as a great power. Both countries have set a new goal of national rejuvenation since the beginning of the 21st century and have become representatives of emerging market countries whose own development requires a solid strategic backing. They are both surrounded by a complex environment with many neighboring countries, including competitors and potential rivals, and serious challenges. Russia's strategic space has been gradually eroded and compressed due to the pressure of NATO and EU's enlargement to the east and the severe sanctions by the US and Europe after the Ukraine crisis. Meanwhile, China, in the 
east, is also faced with potential threats from the U.S.-Japan Security Treaty and the U.S. Indo-Pacific Strategy. In other words, both China and Russia need to rely on each other at the regional level, in which regard SCO is playing an important part to help expand their influence in the hinterland of Eurasia and improve international competitiveness.

Both China and Russia are active forces in maintaining regional peace and in want of a favorable international environment. China is still facing the arduous task of economic development. Decades of hard work are still needed to catch up with the living standards of the world's moderately developed countries even after successfully achieving its first centennial goal and the task of poverty eradication and building a moderately prosperous society. In the long run, China needs not only a steady domestic environment, but also a stable international environment, especially a favorable neighboring environment. Russia, on the other hand, is tasked with getting rid of economic difficulties, achieving geographically balanced development, establishing a good economic order, restructuring its own economy, and expanding its foreign economic ties. All these tasks will not be fulfilled without a favorable international environment (Кортунов, 2021), which is consistent with China's fundamental starting point. International cooperation in the neighborhood and the wider Eurasia, especially through new regional cooperation mechanisms, such as SCO, which introduces "Russian-Chinese solutions" to regional problems, is essential for both countries to maintain their status as regional powers, improve the geopolitical and geo-economic environment, and gain a greater voice in regional affairs.

\subsection{Promote Multipolarization and Improve the Global and Regional Governance System}

The world is witnessing a transition that is unprecedented for hundreds of years. On the one hand, détente has become the mainstream, and peace and development have become more and more important in international relations. On the other hand, instability still exists in many regions, and some superpowers haven't abandoned their Cold War mentality and hegemonic practices. The escalation of geopolitical games has complicated the international landscape and increased security challenges, some of which are highlighted by the end of the Cold War, such as economic friction, territorial (waters) disputes, while others, due to some countries going the other way, wantonly break the norms of international law and meddle or interfere in the internal affairs of other countries, even resort to military force.

The world that China and Russia are facing is still a diverse world. Both China and Russia emphasize that they acknowledge and respect diversity, treat with 
caution the interests of countries of different kinds, and resolutely oppose letting only one or a few countries represent the interests of other countries in the world. China and Russia believe in the irreversible trend of multipolarization which will be effectively promoted through regional cooperation mechanisms.

Currently, China and Russia have the same or similar views on major international issues and hope to jointly facilitate the formation of a just and reasonable international order and the democratization of international relations. The two countries call for a just and fair international political and economic order and security landscape, and support multiform, multilevel and multi-channel regional security dialogues and cooperation on the basis of equal participation, consensus, seeking common ground while reserving differences, and steady progress. China and Russia advocate mutual understanding and trust among countries, and peace and stability in the world. They communicate and exchange views in a timely manner on issues regarding international counter-terrorism and the U.N. reform. Also, more possibilities for Sino-Russian cooperation in the international arena have been created by SCO. As permanent members of the U.N., China and Russia are the world's major political powers. They advocate strengthening the role of the United Nations, emphasize the importance of complying with the purposes of the U.N. Charter and universally recognized norms of international law, and adhere to such basic principles as respect for sovereignty and territorial integrity and non-interference in other countries' internal affairs. Since its establishment, SCO was soon entitled the observer status in the U.N. General Assembly, cooperated with the U.N. and its subordinate bodies, and promoted its policy ideas from the U.N. rostrum, all of which in fact is inseparable from the efforts of China and Russia.

\section{Sino-Russian Cooperation within the SCO Framework}

The year 2021 marks the 20th anniversary of the establishment of SCO, and the 20th anniversary of the signing of Sino-Russian treaty of good-neighborliness and friendly cooperation. The coincidence of the two important dates reflects the special nature of the Sino-Russian comprehensive partnership of coordination. Since the beginning of the Shanghai Five mechanism, China and Russia have become more and more aware of the importance of regional cooperation. The Agreement on ConfidenceBuilding in the Military Field Along the Border Areas signed in Shanghai in 1996 and the Agreement on the Mutual Reduction of Military Forces in the Border Areas signed in Moscow in 1997 were the product of the enhanced political trust and military-security cooperation between China and Russia, and became a starting point of the multilateral framework. At a time when Central Asia is facing serious security problems with the 
“Three Forces” proliferating, China and Russia have simultaneously expressed their concern and sought to maintain stability in Central Asia by strengthening multilateral cooperation. In addition, the institutionalization of such high-level multilateral consultations has led to the successful negotiations on border dispute between China, Russia and Central Asian countries (Xing \& Sun, 2007, pp. 31-32).

The establishment of the SCO marked a major product of the Sino-Russian strategic partnership of collaboration established in 1996, and it also led to a broader range of cooperation between the two sides. Together, China, Russia and Central Asian countries have continued to promote multilateral cooperation across a wide spectrum from security to economy, people-to-people and cultural exchanges and international affairs. Accompanied with the development of multilateral organizations, bilateral cooperation has also entered a new stage. China enjoys sound bilateral relations with Russia and Central Asian countries, frequent exchange of visits at various levels and in various fields, and increasingly enhanced level of economic and trade cooperation. Sino-Russian relations, and relations between China and Central Asian countries, are mutually influential and reinforcing. A new paradigm of state relations has been created thanks to the constant expansion and upgrading of SinoRussian political relations, represented by the signing of the Treaty of GoodNeighborliness and Friendly Cooperation between the People's Republic of China and the Russian Federation, and the further upgrading of bilateral relations to a comprehensive strategic partnership of coordination in 2011. Taking this as the basis and beginning, China has signed similar cooperation treaties with Kazakhstan, Kyrgyzstan, Uzbekistan and other Central Asian countries, and has established strategic partnerships with all Central Asian countries, including comprehensive strategic partnerships with four SCO member states-Kazakhstan, Ukraine, Kyrgyzstan, and Tajikistan. China's desire for befriending Russia and its Central Asian neighbors for generations was thus inscribed in legal form in a series of important bilateral documents, which constitute a necessary guarantee for the development of long-term multilateral cooperation relations. On this basis, in 2007, SCO also signed the Treaty on Long-Term Good-Neighborliness, Friendship and Cooperation between the Member States of the Shanghai Cooperation Organization, which became the most important and fundamental legal document.

In recent years, both China and Russia have made some adjustments in their foreign policies. China adheres to the policy of "building friendship and partnership with neighboring countries" to create an amicable, secure and prosperous neighborhood. To strengthen good neighborliness with neighboring countries, including Russia and Central Asian countries, and to promote regional cooperation, are important cornerstones of China's foreign policy. As for Russia, Putin's administration adopts more pragmatic foreign policies, not only developing traditional relations with Europe, but also attaching importance to cooperation 
with China and other Asian countries, and consolidating Russia's position in the Commonwealth of Independent States (CIS) and Eurasia as a priority of Russian diplomacy. Putin has proposed a "Turn to the East" diplomatic policy, reorienting his priorities to further cooperation with China and other Asian countries. In the strengthened Sino-Russian regional cooperation, the principle of non-alignment and "not directing at third countries" created a new cooperative model, which is fully reflected in the SCO development.

The development of SCO is determined by political, economic, geopolitical and cultural factors. Mutual trust between Russia and China at the regional level has enabled the organization to withstand the changing situation in Central Asia and strengthen its cohesion ( $\mathrm{Wu}, 2006)$. China and Russia have also proposed a series of new goals that have increased the SCO's international prestige. The cooperation between the two countries in the SCO includes the following main aspects.

(1) Jointly proposing new concepts and ideas for international relations and regional cooperation. They advocate new principles of win-win cooperation and peaceful settlement of disputes, and agree to enrich the "Shanghai spirit" with new connotations of the times, giving rise to a new type of regional cooperation mechanism.

(2) Jointly maintaining regional peace and stability. They prioritize combating the “Three Forces"-extremism, separatism and terrorism, as well as drug trafficking and other transnational crimes, in security cooperation, and conduct multilateral joint counter-terrorism exercises and intelligence exchanges, to address various non-traditional security challenges (Xu, 2016).

(3) Jointly contributing to the institutional and legal development of the SCO. China and Russia proposed a series of important documents which were approved by the council of heads of SCO, including the Shanghai Convention on Combating Terrorism, Separatism and Extremism, the SCO Charter, Main Directions of the SCO Mid-Term Development Strategy, the SCO Development Strategy until 2025, the SCO Convention on Countering Extremism, the Agreement among the Governments of the SCO Member States on International Road Transport Facilitation, etc.

(4) Jointly promoting cooperation in strategic planning of member states. China and Russia first signed political documents on the Belt and Road Initiative and the Eurasian Economic Union (EAEU); China and EAEU signed an economic cooperation agreement; Russia proposed the "Greater Eurasian Partnership". Both sides advocate to make SCO an important platform for strategic cooperation of member states under the framework of Belt and Road.

(5) Jointly clarifying positions on important international and regional issues. The SCO convened an international conference on Afghanistan to promote the 
peaceful reconstruction process in Afghanistan and to exchange views on historical and practical issues of international concern in order to safeguard the core interests of China and Russia and other member states.

(6) Jointly upholding multilateralism and regarding the SCO as an important pillar of multipolarity and democratization of international relations. The two countries actively participate in improving the global governance system, oppose unilateralism and trade protectionism, and play an active role through the SCO. China has also put forward the idea of building an SCO community of shared destiny, which is also supported by Russia.

\section{Problems Encountered in Sino-Russian Multilateral Cooperation}

Relying on various multilateral mechanisms and frameworks such as the SCO, BRICS, G20, and the ASCCC, China and Russia echo each other on the international stage, including improving the global and regional governance system, jointly maintaining stability and peace in the world, promoting cooperation among countries to combat international terrorism, safeguarding cyber information security, advocating nuclear non-proliferation, and opposing the arms race and weapons of mass destruction. With the help of the U.N. and its subsidiary bodies, the SCO, the G20 and other multilateral platforms, the two countries are engaged in extensive cooperation in addressing climate change, the peaceful use of outer space, the development of the Arctic, etc. There is no conflict between the fundamental interests of China and Russia in regional strategies, but when it comes to specific areas or directions, there are obvious differences in the goals pursued by the two countries. In addition, since the demands for interests are constantly changing with policy adjustments, some differences in multilateral security and economic cooperation inevitably arise, affecting cooperation within the multilateral framework (Zhao, 2012, p. 69).

First, different international political stands. Russia is a traditional European power with a deep-rooted geopolitical mindset in its diplomacy, attaching importance to the preservation of its past sphere of influence. For example, Putin emphasized in a press conference in December 2020 Russia's need to strengthen its geopolitical interests in the CIS region. In his review of Russia's foreign policy in 2020, Fyodor A. Lukyanov, Editor-in-Chief of Russia in Global Affairs, argues that military power has re-emerged as the main tool of foreign policy, with international mechanisms taking a back seat. Having suffered a century of humiliation and a long blockade after the founding of the People's Republic of China, China has stepped onto the international stage with its head high after the reform and opening-up. China pursues a peaceful 
and independent foreign policy, opposes the resort to force or the threat of force in international relations, and actively seeks innovative ideas and initiatives for the peaceful settlement of disputes.

Second, different security interests at the regional level. Within the multilateral framework, on the one hand, Russia's main security concerns are the military pressure from the U.S. and NATO, and how to prevent the continuous erosion of its strategic depth; on the other hand, China needs to fight against separatist forces and maintain national unity and territorial integrity, which is a relatively "real" task with specific goals and missions. Russia's biggest threat is on the land, from its west; China's biggest security challenge is on the sea, from its East. Considering the fact that the two countries hold different security concerns within the multilateral framework, it is thus difficult to realize the expected mutual support and cooperation.

Third, the gap in economic strength differentiates the choice of multilateral cooperation paths. For example, Russia has reservations about strengthening the economic functions of the SCO, so it does not favor the establishment of a free trade zone, and fears that China will use its relatively strong economic power to overtake Russia's influence in Central Asia. China is constantly expanding its opening to the outside world and is more interested in economic cooperation within the multilateral framework, hoping to facilitate trade and investment in regional countries. Russia, in fact, is more interested in the EAUE, which is led by Russia itself, so there are differences in how they steer the regional economic cooperation. The different preferences for cooperation approaches and contents have affected the efficiency of some multilateral mechanisms in which China and Russia jointly participate, including BRICS and ASCC, which are only dialogue and consultation mechanisms with the nature of a forum. There are also huge gaps in their views and evaluations on some major issues, such as the treatment of the U.S. regional strategy, making it difficult to form a real synergy in the international arena.

Fourth, the specific functions of some multilateral frameworks are positioned differently. Both China and Russia want to use multilateral cooperation to improve their neighboring environment, but their own strategic interests dictate different considerations for participation in different multilateral mechanisms. Russia sometimes wants to use the SCO as its bargaining chip when negotiating with the West. Russia, who is about to take over the rotating presidency of the Arctic Council in 2021, invited China to respond on the issue of the Arctic shipping routes in the hope of ending its isolation under the heavy pressure from the West, and Russia can hardly accept that China regards the route as part of the Silk Road. Russia's focus is not on the content of cooperation, but on the need for a geopolitical tool to counter the West.

Finally, there is a problem of competition. Russia positions itself as a European country and its largest trading partner is the European Union; China is located in East 
Asia and its economic and trade partners are mainly Asia-Pacific countries. China and Russia not only cooperate but compete to a certain extent in Central Asia, Southeast Asia, and Africa. For example, they have established their own " $5+1$ ” framework in Central Asia and each holds summits with African countries; Russia leads integration mechanisms in the post-Soviet region such as EAEU, the Collective Security Treaty Organization (CSTO), which are closer and doesn't include China as a member state (Путин, 2011). Russia has doubts about China's Belt and Road Initiative and does not actually participate in the connectivity projects promoted by the Chinese side. After the official signing of the RCEP with China's participation, the Russian media considered it a new challenge for Russia's “Turn to the East” policy, even suggesting that cooperation with China in East Asia will not help modernize the Russian economy due to insufficient local and corporate participation and an irrational trade structure.

\section{Building a Global Partnership Network through Multilateral Mechanisms}

After the Crimean crisis in 2014, Russia's strategic space has been squeezed by the West on all fronts as the international situation has changed dramatically, making Russian leaders increasingly aware of the importance of multilateral cooperation with China. In the new era, China and Russian will stand more closely together, which will be increasingly manifested in various multilateral mechanisms and frameworks jointly participated by the two countries. At the 20th meeting of the SCO Council of Heads, held online in November 2020, President Xi Jinping stressed that we should practice multilateralism with practical actions, uphold the principle of common cooperation, construction and sharing, improve global governance and maintain international order. The SCO should expand its partnership network and play a more active role in international and regional affairs. The leaders of both Russia and China are actively building and expanding a threedimensional global partnership network through their own major diplomatic initiatives, using various multilateral frameworks in which they jointly participate as platforms.

With the protracted pandemic coronavirus, the resulting crisis is having an increasingly far-reaching impact on international relations at both global and regional levels, and the process of multilateral cooperation is being affected. In the face of the pandemic, the economic "inwardness" and conservative policies of all parties are not conducive to the development of multilateral frameworks. And in order to get the economy back on track in the post-pandemic era, it is in the real needs to restore and expand international trade and economic ties as soon as 
possible and rebuild regional industrial and value chains, for which China and Russia are more than ready. In the future, China and Russia will value more highly on the cooperation within the U.N., SCO and other multilateral frameworks. Both countries believe that multilateralism is the trend of the time and that various multilateral organizations and mechanisms are the pillars of international cooperation. In the midst of major international changes, both sides hope that emerging market countries will gain equal rights to rule-making and international discourse, which can only be realized through multilateral arena with larger influence.

China and Russia will not establish and participate in closed economic, political or security frameworks directly targeting the United States and other Western countries, but would rather provide equal development opportunities for more countries by promoting regional openness and integration, so both leaders attach importance to building a broad partnership network. The Chinese leaders have proposed the Belt and Road Initiative and the concept of global governance based on consultation, contribution and shared benefits, thus building a community of shared future for all mankind. The Russian leaders have proposed the "Greater Eurasian Partnership" program, in the hope of a healthy cooperative and interactive relationship between various international mechanisms on the Eurasian continent. Hence, the cooperation between the two countries in multilateral initiatives differs from the traditional international political thinking, but rather advocates openness, transparency, partnership and non-alignment, featuring a broader partnership network. They mutually respect and support each other, whose respective diplomatic initiatives are implemented without conflicts, to actively seek a path of win-win cooperation and development. Besides, the Chinese leaders also propose to build a SCO community of shared destiny and explore feasible paths for regional communities in terms of hygiene and health, security, development and humanities.

\section{Conclusion}

The Sino-Russian Cooperation within the framework of international organizations and mechanisms at global and regional levels, especially the SCO, carries important meaning and constitutes the logical extension of the comprehensive strategic partnership of coordination between the two countries in the new era. It not only expands the geographical space for bilateral cooperation and enriches the areas and levels of cooperation, but also allows for better and stabler strategic interests of both sides in the long term. Heads of the two states are putting more and more value on bilateral cooperation within the multilateral framework, and communication and interaction in various fields and at various levels, making unique contributions to reforming and improving the global governance system. 
These efforts help expand the partnership network, build a new type of international relations, and promote peace and development in the region and the world.

The most typical and exemplary cooperation between Russia and China within the framework of multilateral mechanisms is the joint promotion of the establishment and development of SCO, which reflects the equally high, broad and multi-level cooperation between the two countries at the regional level and represents a new direction of equal cooperation, mutual trust and common development between large and small countries. In the 20 years of SCO cooperation, guided by the "Shanghai Spirit”, the leaders of China and Russia have creatively put forward many new concepts and ideas of cooperation, adhered to the principle of cooperation in partnership and non-alignment, and actively created a new model of regional cooperation. Cooperation between the two countries in multilateral mechanisms such as the United Nations and its subsidiary bodies, the G20, BRICS, Asia-Pacific Economic Cooperation, and the Conference on Interaction and Confidence-building Measures in Asia (CICA) is also fruitful and conducive to the advancement of political multipolarity and democratization of international relations.

As two world powers, it is normal to have differences in interests and goals on regional issues, which have not become substantial obstacles to the two's cooperation at the multilateral level. Russia and China are able to respect and recognize the differences in interests, coordinate their concerns through high-level consultations and reach the broadest consensus on cooperation, without limits or forbidden zones. Looking forward, with the complicated changes in the international situation and relations between major powers, especially in the postpandemic era when the global economic, political and security landscape will undergo significant adjustments, it will take strenuous efforts for mankind to completely emerge from this sudden outbreak of crisis. The cooperation between China and Russia in multilateral mechanisms and frameworks is not only in line with the needs of the times and beneficial to the multilateralism, but also a way for the two neighboring powers to achieve strategic interaction on a larger stage and explore new models of regional and even global governance, which can play a pivotal role in the healthy development of international relations.

\section{References}

Wu, D. H. (2006). The triple aspiration of the U.S. To stimulate color revolutions in the CIS region: The urgent need for China and Russia to resist color revolutions under the framework of the Shanghai Cooperation Organization. Russian, East European and Central Asian Studies, (2), 1-8.

Xing, G. C., \& Sun, Z. Z. (2007). On the Shanghai Cooperation Organization. Changchun: Changchun Press. 
$\mathrm{Xu}, \mathrm{T}$. (2016). The trend of diversified non-traditional security threats in Central Asia. Journal of International Security Studies, (5), 79-94.

Yang, J. (2017). Security cooperation of the Shanghai Cooperation Organization. Academic Journal of Russian Studies, (3), 77-85.

Zhao, H. S. (2012). Shanghai Cooperation Organization-evaluation and prospects. Beijing: Beijing Current Affairs Press.

Кортунов, А. (2021). Внешняя политика России в 2021 г.: четырнадчать практических задач. РСМД: Российский совет по международным делам. https://russiancouncil.ru/ analytics-and-comments/analytics/vneshnyaya-politika-rossii-v-2021-g-chetyrnadtsatprakticheskikh-zadach/

Путин, В. (2011, 3 октября). Новый интеграчионный проект для Евразии - будущее рождается сегодня. Известия. 